\title{
MEMBANGUN JARINGAN PASAR UNTUK MENGEMBANGKAN USAHA PRODUK LOKAL DALAM MENUMBUH KEMBANGKAN USAHA BERBASIS SUMBER DAYA LOKAL MELALUI USAHA MIKRO DAN KEUANGAN MIKRO
}

\author{
Bakti Toni Endaryono, ${ }^{1)}$ Tjipto Djuhartono ${ }^{2)}$ \\ ${ }^{1)}$ Program Studi Ekonomi Syariah IAIN Laa Roiba, \\ ${ }^{2)}$ Program Studi Pendidikan Ekonomi Universitas Indraprasta PGRI \\ Email : baktitoni@gmail.com; tjiptodjuhartono@gmail.com
}

Diterima: Oktober 2018; Disetujui: Nopember 2018; dipublikasikan: Desember 2018

\begin{abstract}
ABSTRAK
Berbagai persoalan yang terjadi pada masyarakat saat ini dijaman era digital yaitu revolusi industry 4.0 adalah salah satunya terjadinya tingkat kesejahteraan yang belum merata dikalangan masyarakat khususnya di pedesaan , maka dengan menumbuhkan usaha kecil mikro dengan berbasis sumber daya lokal dan meningkatkan sumber daya lokal yang ada pendampingan di masyarakat itu sendiri maka tingkat kesejahteraan keluarga dan masyarakat akan tercapai dengan adanya kemandirian masyarakat untuk meningkatkan produk lokal yang ada dipedesaan, dengan cara membangun jaringan pasar khususnya pemasaran produk lokal di pasar tradisional, pasar modern serta membangun jaringan dengan dinas koperasi dan perdagangan terkait ditingkat kabuaten adat kota maka sumber daya lokal yang ada dengan melalui kelompok usaha kecil mikro yang didukung oleh keuangan mikro,untuk meningkatkan pendapatan keluarga dan masyarakat akan tercapai
\end{abstract}

Kata kunci : Mengembangkan, usaha, produk lokal, usaha mikro dan keuangan mikro

\begin{abstract}
Various problems that occur in society today in the era of the digital era, namely the industrial revolution 4.0 is one of them is the level of welfare that has not been evenly distributed among the community, especially in rural areas, then by growing micro-small businesses based on local resources and increasing local resources that have assistance in the community itself, the level of welfare of the family and the community will be achieved with the independence of the community to improve local products in the countryside, by building a market network especially marketing local products in traditional markets, modern markets and building networks with cooperative offices and related trade at the adat Kabupaten level the city, the local resources available through micro small business groups supported by microfinance, to increase family and community income will be achieved
\end{abstract}

Keywords: Developing, business, local products, Micro Enterprises, and Microfinance 


\section{Sosio e-kons}

Volume 10, No. 3, Desember 2018, pp. 228-233

e-ISSN: 2502-5449

p-ISSN: 2085-2266

http://journal.lppmunindra.ac.id/index.php/sosio_ekons

DOI: http://dx.doi.org/10.30998/sosioekons.v10i3.2793

\section{PENDAHULUAN}

Tulisan ini diharapkan dapat memberi dampak yang baik terhadap pengembangan masyarakat khususnya para usaha kecil produk lokal, dengan cara melakukan pendampingan kepada masyarakat secara intensif dan mendorong untuk dapat membuat usaha kecil dilingkungan masyarakat, saat ini pelaku usaha mikro dimasyarakat masih kurang untuk menghadapi jaman globalisasi dengan revolusi industry 4.0, terutama diindonesia, walaupun disadari bahwa masih sangat kurang untuk mencapai kondisi yang ideal dalam peningkatan ekonomi, masih dibutuhkan banyak langkah atau kegiatan yang harus ditindaklanjuti, melalui tulisan ini diharapkan mampu menambah wawasan bagi para calon usaha mikro di masyarakat, yang saat ini tidak hanya focus pada aspek pelayanan kredit simpang pinjaman, dengan cara membangun jaringan pasar , mengembangan usaha produk lokal, membangun jaringan dengan dinas - dinas terkait dengan usaha kelompok untuk meningkatkan kesejahteraan.

Kendala yang dihadapi oleh masyarakat dalam berusaha antara lain keterbatasan waktu, kurang akses terhadap sumber permodalan, jaringan pasar dan informasi, aspek permodalan merupakan kendala utama yang dirasakan oleh masyarakat khususnya dipedesaan yang berkaitan dengan usaha mikro untuk memperoleh kredit dari lembaga perbankkan formal, karena prosedur yang dirasakan sulit dan jaminan yang digunakan.

Dengan diterbitkanya UU/PP/Perda tentang usaha kecil mikro dan keuangan mikro yang berpihak kepada masyarakat maka akan adanya Kebijakan nasional pengembangan keuangan mikro yang adil sebagai landasan filosofi dan platform bersama dalam mengembangkan usaha mikro, kecil dan menengah serta terbentuknya jaringan pasar dan kerja sama dinas terkait dalam masyarakat usaha kecil mikro dan keuangan mikro dengan tujuan untuk membangun adanya Forum Peduli masyarakat usaha kecil mikro yang dapat memberikan kontribusi positif yang saling menguntungkan baik bagi LKM maupun pelaku usaha mikro yang ada di desa.

Peningkatan pendapatan merupakan indicator tambahan yang merupakan indicator penting dalam meningkatkan pendidikan, tanpa memiliki pendapatan maka setiap keluarga sulit untuk meningkatkan pendidikan putra-putrinya.

Penelitian terdahulu Bakti Toni Endaryono (2017) "Usaha Kecil Mikro untuk Meningkatkan Kemampuan Daya Beli Kebutuhan bagi Masyarakat Akibat Inflasi" diterbitkan pada Jurnal ilmiah Dunia Ilmu vol III nomor 1 tahun 2017 / www.jurnalmudiraindure.com ISSN 2443-0285

\section{METODE}

Metode dalam penulisan ini menggunakan metode penelitian Empiris (Empirical Research) dimana Penelitian Empiris adalah penelitian terhadap fakta empiris berdasar pengalaman langsung atau pengamatan (observasi) yang ada, adapun data diperoleh dari data sekunder dan literatur yang sesuai dengan kajian serta data primer adalah data yang dikumpulkan oleh penulis sendiri data ini adalah yang belum pernah dikumpulkan sebelumnya, baik dengan cara tertentu atau pada periode waktu

\section{HASIL DAN PEMBAHASAN}

Undang-Undang Nomor 13 tahun 1998 menjelaskan juga tentang arti dari kesejahteraan. Kesejahteraan didefinisikan sebagai suatu tata kehidupan dan penghidupan sosial baik material maupun spiritual yang diliputi rasa keselamatan, kesusilaan, dan ketentraman lahir batin yang memungkinkan bagi setiap warga negara untuk mengadakan pemenuhan jasmani, rohani, dan 


\section{Sosio e-kons}

Volume 10, No. 3, Desember 2018, pp. 228-233

e-ISSN: 2502-5449

p-ISSN: 2085-2266

http://journal.lppmunindra.ac.id/index.php/sosio_ekons

DOI: http://dx.doi.org/10.30998/sosioekons.v10i3.2793

sosial yang sebaik-baiknya bagi diri, keluarga, serta masyarakat dengan menjunjung tinggi hak dan kewajiban asasi manusia sesuai dengan Pancasila.

Dengan pemberdayaan masyarakat melalui membangun jaringan usaha mikro dan keuangan mikro, yakni dalam aspek reformasi, investasi pada usaha mikro maka perlu diberikan kebutuhan strategis melalui.

a. Kebijakan nasional pengembangan keuangan mikro yang adil sebagai landasan filosofi dan platform bersama dalam mengembangkan produk lokal, usaha mikro, kecil dan menengah serta perkembangan kelompok masyarakat

b. Kerangka hukum bagi lembaga keuangan mikro (LKM) dalam bentuk UU/PP atau paling tidak Perda sebagai payung legalitas LKM di daerah.

c. Pelatihan bagi masyarakat untuk peningkatan kapasitas usaha produk lokal, usaha mikro dan menengah dalam hal, produk, pemasaran, akses kredit, membangun jaringan pasar dan lain lain

d. adanya Forum Peduli masyarakat usaha kecil mikro yang dapat memberikan kontribusi positif yang saling menguntungkan baik bagi LKM maupun pelaku usaha mikro khususnya produk lokal yang ada pada masyarakat

\section{Kemandirian Masyarakat}

Kemandirian disini menyiratkan suatu kemampuan otonom untuk mengambil keputusan bertindak berdasarkan keputusannya itu dan memilih arah tindakan sendiri tanpa terhalang oleh orang/pihak lain. Khususnya bagi masyarakat untuk meningkatkan pendapatanya melalui usaha sendiri dengan meningkatkan produk lokal yang ada di masyarakat. Tanpa kemandirian maka sulit bagi masyarakat untuk meningkatkan kesejahteraan keluarga melalui peningkatan pendapatan asrori $(2008 ; 109)$

\section{Kemandirian Pembinaan (pendampingan)}

Yaitu kemampuan otonom masyarakat untuk membina diri mereka sendiri dalam bentuk pengelolaan tindakan kolektif yang membawa pada perubahan kehidupaan mereka. Dengan cara memberikan pengetahuan tentang usaha, pendampingan ditingkat desa guna untuk memberikan kesadaran kritis bagi masyarakat pentingnya meningkatkan pendapatan (Sebagai catatan : dalam proses pendampingan ada intervensi pendamping untuk memberikan kesadaran kritis dan wawasan bagi masyarakat, maka pada tahapan kemandirian pendamping kelompok masyarakat berasal dari dalam).

Kemandirian masyarakat merupakan suatu kondisi yang dialami oleh masyarakat yang ditandai dengan kemampuan memikirkan, memutuskan serta melakukan sesuatu yang dipandang tepat demi mencapai pemecahan masalah-masalah yang dihadapi dengan mempergunakan daya kemampuan yang dimiliki. Daya kemampuan yang dimaksud adalah kemampuan kognitif, konatif, psikomotorik dan afektif serta sumber daya lainnya yang bersifat fisik/ material. Kemandirian masyarakat dapat dicapai tentu memerlukan sebuah proses belajar. Masyarakat yang mengikuti proses belajar yang baik, secara bertahap akan memperoleh daya, kekuatan atau kemampuan yang bermanfaat dalam proses pengambilan keputusan secara mandiri. Berkaitan dengan hal ini, Sumodiningrat (2000) menjelaskan bahwa keberdayaan masyarakat yang ditandai adanya kemandiriannya dapat dicapai melalui proses pemberdayaan masyarakat.

\section{Menumbuh Kembangkan usaha berbasis sumber daya lokal}

Jiwa usaha adalah salah satu yang harus dimiliki setiap orang apalagi usaha dengan meningkatkan produk lokal yang ada dilingkungan masyarakat saat ini, dengan meningkatkan produk lokal yang dijadikan usaha kecil menengah maka secara otomatis akan meningkatkan pendapatan keluarga khususnya dan masyarakat umumnya, sehingga setiap masyarakat mampu meningkatkan dan mengembangkan produk lokalnya agar dapat dijadikan sebagai produk unggulan di daerah tersebut. 


\section{Sosio e-kons}

Volume 10, No. 3, Desember 2018, pp. 228-233

e-ISSN: 2502-5449

p-ISSN: 2085-2266

http://journal.lppmunindra.ac.id/index.php/sosio_ekons

DOI: http://dx.doi.org/10.30998/sosioekons.v10i3.2793

Menurut suryana (2003) bahwa orang yang memiliki jiwa usaha adalah memiliki ciri-ciri :

1) Percaya diri (yakin, optimis dan komitmen

2) Percaya diri dalam menentukan sesuatu dan percaya diri dalam menjalankan sesuatu usaha dan percaya diri dalam mengatasi berbagai resiko yang dihadapi dalam berusaha, karena itu adalah factor dasar yang harus dimiliki oleh wirausaha

3) Berinisiatif ( energik)

4) Seorang wirausaha akan selalu berusaha mencari jalan keluar karena tidak ingin bergantung kepada orang lain'

5) Memiliki jiwa kepemimpinan

6) Menyukai tantangan baru

\section{Usaha Mikro}

Usaha mikro adalah usaha yang bersifat menghasilkan pendapatan dan dilakukan oleh rakyat miskin atau mendekati miskin. Sedangkan Pengusaha Mikro adalah orang yang berusaha di bidang usaha mikro. Ciri-ciri usaha mikro antara lain: "modal usahanya tidak lebih dari Rp 10 juta (tidak termasuk tanah dan bangunan), tenaga kerja tidak lebih dari lima orang dan sebagian besar mengunakan anggota keluarga/kerabat atau tetangga, pemiliknya bertindak secara naluriah/alamiah dengan mengandalkan insting dan pengalaman sehari-hari." P2KP, "Mengenal Kelompok Usaha Mikro," http://www.p2kp.org/wartaarsip detil.asp? mid=1094\&catid=2\& diakses 12 november 2017 jam 21.00 wib.

Usaha kecil sebagai kegiatan ekonomi rakyat berskala kecil memiliki peran sentral dalam perekonomian Indonesia. Walaupun krisis ekonomi telah memporakporandakan kehidupan bidang usaha besar dan menengah, ternyata usaha kecil tetap tegar dan berjalan marak dikawasan kehidupan ekonomi tingkat bawah.

Peran pokok usaha kecil ini adalah: (1) sebagai penyerap tenaga kerja, (2) sebagai penghasil barang dan jasa pada tingkat harga yang terjangkau bagi kebutuhan rakyat banyak yang berpenghasilan rendah, (3) sebagai penghasil devisa negara yang potensial kerena keberhasilannya dalam meproduksi komoditi ekspor non migas.

Mengingat peran usaha kecil tersebut sangat besar andilnya bagi negara dan masyarakat kecil dilapisan bawah, maka pembinaan dan pengembangannya sangat perlu diperhatikan. Pasal 1 angka (1) Undang-Undang No. 20 Tahun 2008 tentang Usaha Mikro, Kecil dan Menengah menyebutkan: "Usaha Mikro adalah usaha produktif milik orang perorangan dan/atau badan usaha perorangan yang memenuhi kriteria Usaha Mikro sebagaimana diatur dalam Undang-Undang ini."

Pada Pasal 6 ayat (1) menyebutkan kriteria yang harus dipenuhi agar dapat disebut sebagai usaha mikro, yaitu: Memiliki kekayaan bersih paling banyak Rp50.000.000,00 (lima puluh juta rupiah) tidak termasuk tanah dan bangunan tempat usaha; atau Memiliki hasil penjualan tahunan paling banyak Rp300.000.000,00 (tiga ratus juta rupiah. Pasal 1 angka (8) Undang-Undang No. 20 Tahun 2008 tentang Usaha Mikro, Kecil dan Menengah memberikan pengertian pemberdayaan sebagai upaya yang dilakukan Pemerintah, Pemerintah Daerah, dunia usaha, dan masyarakat secara sinergis dalam bentuk penumbuhan iklim dan pengembangan usaha terhadap usaha mikro, kecil, dan menengah sehingga mampu tumbuh dan berkembang menjadi usaha yang tangguh dan mandiri.

Upaya yang dilakukan oleh Pemerintah Daerah, untuk membantu dan memfasilitasi masyarakat untuk memberdayakan usaha mikro, kecil, dan menengah melalui pemberian fasilitas, bimbingan, pendampingan, jaringan pasar dan bantuan perkuatan untuk menumbuhkan dan meningkatkan kemampuan dan daya saing usaha mikro, kecil, dan menengah.

\section{Keuangan Mikro}

Peran dan tanggungjawab pemerintah dalam sektor keuangan sampai saat ini masih dibutuhkan. Namun, partisipasi masyarakat khususnya pihak swasta sangat diharapkan untuk mendorong perkembangan dan kemajuan di sektor keuangan di Indonesia, termasuk partisipasi 


\section{Sosio e-kons}

Volume 10, No. 3, Desember 2018, pp. 228-233

e-ISSN: 2502-5449

p-ISSN: 2085-2266

http://journal.lppmunindra.ac.id/index.php/sosio_ekons

DOI: http://dx.doi.org/10.30998/sosioekons.v10i3.2793

masyarakat dalam kegiatan perbankan maupun non-perbankan. Pemerintah harus terus mendorong masyarakat untuk berpartisipasi dan berperan aktif dalam kegiatan di sektor keuangan.

Untuk mengatasi permasalahan tersebut, pemerintah memberikan solusi dengan meluncurkan suatu program yang dinamakan Program Pengembangan Usaha Agribisnis Perdesaan (PUAP) melalui pemberian dana Bantuan Langsung Masyarakat (BLM) sebagai modal usahatani bagi petani, sekaligus untuk memperbaiki dan memperkuat kelembagaan ekonomi di perdesaan yang akhirnya bermuara pada berkembangnya Lembaga Keuangan Mikro Agribisnis (LKM-A) di perdesaan.

Diakui bahwa perbankan sebagai lembaga keuangan sampai saat ini telah menunjukkan suatu kemajuan yang signifikan terhadap perekonomian nasional dan ekonomi daerah yang terbukti dari pesatnya pertumbuhan lembaga perbankan (bank) di berbagai daerah di Indonesia, baik di kota maupun di kabupaten. Oleh karena itu adalah wajar apabila sektor perbankan menjadi sangat dominan dalam kegiatan usaha jasa keuangan di Indonesia sampai saat ini.

Sumber modal bagi usaha mikrokecil dan menengah terbagi menjadi dua yaitu modal sendiri dan modal dari luar,Penguatan modal erat hubungannyadengan pemberdayaan. Pemberdayaan dapat disamakan dengan keberhasilan usaha. Artinya, tolak ukur pemberdayaan dapat disamakan dengan tolak ukurkeberhasilan usaha. Keberhasilan usaha dapat diukur dari berbagai segi. Diantaranya dari laba usaha yang berhasil dicapai oleh para pengusaha dalam kurun waktu tertentu. Keberhasilan usaha juga diidentikkan dengan perkembangan perusahaan, yaitu proses peningkatan kuantitas dan dimensi perusahaan. Perkembangan perusahaan adalah pertambahan karyawan, peningkatan aset, pendapatan dan lain-lain (Jarkasih,2008:41 -45)

Dengan dilakukanyan pendampingan melalui pengabdian masyarakat bahwa pentingnya pendampingan memberikan pengetahuan kepada masyarakat khususnya bagi pelaku usaha kecil dan usaha kelompok selain mengakses permodalan melalui lembaga keuangan (Bank) maka perlu diberikan pengetahuan tentang bagaimana dapat mengakses modal tanpa melalui bank tetapi melalui usaha kelompok yang tergabung dalam koperasi kelompok, pengetahuan ini sangat penting bagi masyarakat karena untuk mengakses modal melalui bank masih sulit dirasakan masyarakat terkait dengan kelayakan usaha produk lokal masyarakat yang belum memenuhi standar kelayakan bank. Maka strategi yang dilakukan pendampingan pada pengabdian masyarakat ini adalah dengan memberikan pengetahuan tentang " pendidikan Keuangan untuk perempuan matang" pendidikan itu diberikan berdasarkan kreteria masyarakat yang memiliki usaha produk lokal dengan rata - rata umur diatas 40 tahun, dimana materi yang diberikan berupa, membentuk prakoperasi, dan koperasi serta bagaimana membuat tabungan untuk masa depan.

\section{SIMPULAN}

Dengan diterbitkanya UU/PP/Perda tentang usaha kecil mikro dan keuangan mikro yang berpihak kepada masyarakat maka akan adanya kebijakan nasional pengembangan keuangan mikro yang adil sebagai landasan filosofi dan platform bersama dalam mengembangkan usaha mikro, kecil dan menengah serta terbentuknya jaringan pasar dan kerja sama dinas terkait dalam masyarakat usaha kecil mikro dan keuangan mikro dengan tujuan untuk membangun adanya Forum Peduli masyarakat usaha kecil mikro yang dapat memberikan kontribusi positif yang saling menguntungkan baik bagi LKM maupun pelaku usaha mikro yang ada di desa.

Maka strategi yang dilakukan pendampingan pada pengabdian masyarakat ini adalah dengan memberikan pengetahuan tentang " pendidikan Keuangan untuk perempuan matang” pendidikan itu diberikan berdasarkan kreteria masyarakat yang memiliki usaha produk lokal dengan rata rata umur diatas 40 tahun, dimana materi yang diberikan berupa, membentuk prakoperasi, dan koperasi serta bagaimana membuat tabungan untuk masa depan 


\section{Sosio e-kons}

Volume 10, No. 3, Desember 2018, pp. 228-233

e-ISSN: 2502-5449

p-ISSN: 2085-2266

http://journal.lppmunindra.ac.id/index.php/sosio_ekons

DOI: http://dx.doi.org/10.30998/sosioekons.v10i3.2793

\section{SARAN}

Diharapkan pemerintah kabupaten dan kota dapat mengaplikasikan dan menjalankan Undang-Undang Nomor 13 tahun 1998 serta menjelaskan juga tentang arti dari kesejahteraan karena sangat penting bagi peningkatan kesejahteraan hidup khususnya keluarga yang ada di pedesaan. Diupayakan Pemerintah Daerah membantu dan memfasilitasi masyarakat untuk memberdayakan usaha mikro, kecil, dan menengah melalui pemberian fasilitas, bimbingan, pendampingan, jaringan pasar dan bantuan perkuatan untuk menumbuhkan dan meningkatkan kemampuan dan daya saing usaha mikro, kecil, dan menengah

\section{DAFTAR RUJUKAN}

Endaryono, B. T. (2017). Indikator Pembangunan Pendidikan Untuk Masyarakat Berkelanjutan Dengan Pendidikan Berkarakter Di Indonesia. Faktor Jurnal Ilmiah Kependidikan, 4(3), 301-306.

Endaryono, B. T., Paramansyah, A \& Djuhartono, T. (2018). Peran Kinerja dapat Meningkatkan Pendapatan untuk Peningkatan Ekonomi Keluarga Menurut Perspektif Islam. Sosio e-kons, 10(1), 11-19.

Endaryono, B.T. (2017) usaha kecil mikro untuk meningkatkan kemampuan daya beli kebutuhan bagi masyarakat akibat inflasi. www. Jurnalmudiraindure.com

Glendoh, S. H. (2004). Pembinaan dan pengembangan usaha kecil. Jurnal Manajemen dan Kewirausahaan, 3(1), 1-13.

Hermawan, H \& Andrianyta, H. (2016). Lembaga keuangan mikro agribisnis: terobosan penguatan kelembagaan dan pembiayaan pertanian di perdesaan. Analisis Kebijakan Pertanian, 10(2), 143-158.

Kementerian Koperasi dan UKM. 2012. Perkembangan Data Usaha Mikro, Kecil, dan Menengah (UMKM), dan Usaha Besar (UB) Tahun 2011-2012. [internet]. [diunduh 2013 Desember 3]. Tersedia pada: http://www.depkop.go.id

Pradhana, H. P \& HR, M. N. (2017). Penguatan Modal Usaha Mikro, Kecil Dan Menengah Melalui Pembiayaan Di BMT Mandiri Sejahtera Gresik. Jurnal Ekonomi Syariah Teori dan Terapan, 3(4), 325.

Sunartiningsih, A. (2004). Strategi Pemberdayaan Masyarakat. Aditya Media bekerjasama dengan Jurusan Sosiatri Fakultas Sosial Ilmu Politik, Universitas Gadjah Mada.

Supriyanto. (2006). Pemberdayaan Usaha Mikro, Kecil, dan Menengah (UMKM) Sebagai Salah Satu Upaya Penanggulangan Kemiskinan. Jurnal Ekonomi dan Pendidikan. 3(1): 1-17. 